\title{
DIE BEELD VAN GOD VOLGENS DIE NUWE TESTAMENT
}

Hoofsaaklik maak die nutestamentiese skrywers gebruik van die woord eikōn wanneer gespreek word van die beeld van God. Maar eikōn word nie net gebruik by die aanduiding van die beeld van God nie; soos in die Oue Testament word die woord ook gebruik ter aanduiding van afgodsbeelde; dan is dit natuurlik te verstaan as sinoniem van die woord eidolon. Ook in die klassieke en hellenistiese Grieks word eikön heel dikwels gebesig vir 'n gesnede beeld. Ons ondersoek het egter slegs ten doel om nader rekenskap te gee van die woord eikōn vir sover dit betrekking het op die beeld van God in die Nuwe Testament; dit bring mee dat ons ons ondersoek sal inperk tot die betekenisse wat $e i k o ̄ n$ het wanneer dit die relasie tussen 'n lewende wese en sy beeld wil weergee. Behalwe in die $\mathrm{Ou}$ en die Nuwe Testament word die woord in dié sin ook aangetref in die klassieke en hellenistiese Grieks; ook die rabbynse opvatting oor die begrip ",beeld" kan ons dienste bewys by ons ondersoek na die nutestamentiese betekenis van die woord.

Met hierdie as uitgangspunt, kan die ondersoek hom ten beste aanknoop by $\mathrm{Mt}$. 22: 20 en paralelle plekke wat meteen ook die eerste vermelding is van die woord eikōn in die Nuwe Testament. Nadat op sy versoek, die joodse ondervraers van Jesus aan hom 'n muntstuk vertoon het, het hy die vraag gestel: Wie se beeld (eikön) en opskrif is hierdie? Die bekende antwoord van Jesus en die verleentheid van sy ondervraers daarmee, wys dat én Jesus én hulle 'n bepaalde opvatting gehad het oor die beeld van die keiser. Die beeld is vir hulle nie net 'n onpersoonlike hreeltnis nie maar dit is verteenwoordigend van hom waarvan dit die beeld is; die beeld van die keiser is die teken van sy gesag, sy majesteit, sy heerlikheid. In dieselfde rigting wys 'n sinsnede by Arrianus: Wie se stempel (charaktêr) dra hierdie tetrasarion ('n munt)? Die antwoord lui: Die van Trajanus. ${ }^{1}$ ) Ter verklaring van hierdie opvatting haal Plummer 'n opinie van Maimonides aan: Ubicunque numisma alicuius regis obtinet, illic incolae regem istum pro domino agnoscunt. ${ }^{2}$ )

Hierdie was die algemeen oosterse opvatting oor die betekenis van die beeld van 'n lewende persoon. Hieraan verwant was die hellenistiesoosterse gebruik om die koning aan te sien as die beeld van die godheid, i.s.v. hy die draer is van die heerlikheid en die gesag van die godheid. Ptolemaeus Epiphanes word om die tede genoem eikōn zōsa tou Dios

1) Arrian, Epict. iv. 5. 17.

2) Plummrr, The Gospel according to St. Luke (Int. Crit. Comm.) 5th Ed., Edinburgh 1942, p. 466. 
(lewende beeld van Zeus). ${ }^{3}$ ) Netso heet Philopater met egiptiese koningstitulatuur eikōn tou Dios (beeld van Zeus). ${ }^{4}$ ) Plutarchos laat 'n Pers die houding van sy volk uitspreek teenoor die koning: „Vir ons is die beste van ons baie goeie wette hierdie een: om die koning te eer en hom te anbid as die beeld van God ..."'5)

Vanselfsprekend sal in die rabbynse literatuur nie 'n opinie aangetref word wat ooreenkom met die oosterse gedagte dat die vors die beeld van God is nie; wel vind ons by die rabbyne bevestiging vir die opvatting dat 'n vors se heerskappy net so vér strek as wat sy munte geldig is. In hierdie verband spreek die Talmud van die munte van Saul en Dawid. ${ }^{6}$ ) En dat volgens die rabbynse voorstelling die munte in die vroeëre geskiedenis van hul volk wel beelde gedra het, getuig die volgende vertellinge: Abraham se munte het aan die een kant die beeld gedra van 'n grysaard en 'n ou vrou en aan die ander kant dié van 'n jong man en 'n jong vrou. ${ }^{7}$ ) Mordegai se munte het aan die een kant sy eie beeltnis gehad en aan die ander kant, dié van Esther. Hierdie munt het in die sfeer van die heerskappy van Mordegai gesirkuleer. ${ }^{8}$ ) Die rabbyne het dit ook met soveel woorde uitgespreek dat iemand se muntreg staan en val met sy heerskappy. ${ }^{\circ}$ ) Hulle het die mag van 'n heerser selfs sy "munt" genoem. ${ }^{10}$ ) Dus ook by die laat-jodendom tref ons die voorstelling aan dat beeld en heerskappy of majesteit of heerlikheid met mekaar verbonde is. Hierdie verband tussen iemand se beeld en sy heerlikheid, word ook aangetref in die Nuwe Testament. Ons het reeds gewys op die voorstelling in Mt. 22:20; wanneer daar in die Openbaringe gespreek word van ,die dier en sy beeld", 11) dan weet ons dat dit betrekking het op die romeinse-keiser Domitianus en sy standbeeld. Laasgenoemde is nie voorgestel as ' $n$ blote stuk beeldhou-werk van meer of mindere estetiese waarde nie maar dit was die representant van die keiser en het sy genus geherberg; as sodanig was dit die voorstelling van sy majesieit en heerlikheid. Ede is daarom ook by die beeld van die keiser gesweer en as teken van lojaliteit teenoor die keiset en die staatsgodsdiens is die beeld van die keiser aanbid. Dit was juis die metode wat deur Plinius gevolg is om die christelike belydenis van onderdane in die ptovinsie Bithynia, te toets; wou hulle nie voor die beeld van die keiser anbid nie, dan was hulle christene en strafbaar. ${ }^{12}$ )

2) DitTenberger, O.G.I. 90.3

) Mitteis-Wilcken, I. 2. Nr. 109.

s) Plut., Themistocles 27.

C) Sanh. 2. 20b; Meg. 14b.

7) Gen. R. 39.

) Midr. Esth. 8. 15.

9) Sanh. 1. 15.

10) Ex. R. 15.

11) Openb. 13:14, 15;14:9,11;15:2;16:2;19:20;20:4.

12) Punnus, Ep. ad Trajan. 96. 
Maar moet die beeld nou gesien word as 'n tweede, 'n geobjektiveerde grootheid naas dit waarvan dit die beeld is? Die antieke denke het so 'n opvatting nie geken nie. Vir hulle het die beeld deel uitgemaak van die wese van die saak; die beeld is beeld van die kern van die saak. Hulle voorstelling van die beeld en dit waarvan dit die beeld is, was nie 'n dualistiese nie, maar 'n monistiese voorstelling. ${ }^{13}$ ) 'n Tekenende voorbeeld hiervan word reeds aangetref by Plato wanneer hy van Helios praat as die beeld van die „eie-aard van die goeie" (idea tou agathou).14) Dieselfde monistiese voorstelling word ook aangetref by Plutarchos, Stobaeus en in die hermetiese literatuur. ${ }^{15}$ ) Die beeld van die godheid of die beeld van die heerser stel dus nie voor 'n tweede grootheid naas die godheid of naas die heerser nie, maar dit is die verteenwoordiging van die heerlikheid van die godheid of die heerser.

Nou is dit natuurlik nie voldoende om, vir die bepaling van die inhoud van ,beeld" in die Nuwe Testament, net die betekenis daarvan in die griekse, hellenistiese en rabbynse literatuur na te gaan nie; bepalend vir die begrips-inhoude van die nutestamentiese woorde is in die eerste plek die bedoeling van die $\mathrm{Ou}$ Testament met die woorde. Ons sal dus die betekenis van ",beeld" in die Ou Testament ook nader moet besien terwyl steeds in gedagte gehou word dat die Septuagint, die griekse vertaling van die Ou Testament, in die algemeen die agent is wat aan hebreeuse woorde hul griekse kleed verskaf waarmee hul ook in die Nuwe Testament oorgeneem word.

Ter aanduiding van die beeld van God, gebruik die Ou Testament steeds die woord, çèlem. En dit is opvallend dat in bykans elke geval waar die beeld van God ter sprake kom, die Ou Testament daaraan die idee van heerskappy of gesag of heerlikheid verbind. Dit blyk reeds uit Gen. 1:26 en 27, maar die uitspreek van God's voorneme om mense te maak as sy beeld ${ }^{16}$ ) begelei word deur die sinsnede, ,en laat hulle heers ..." Met ander woorde, Gen. 1 verbind die beeld Gods al met die gedagte van heerskappy, of om die begrip meer omvattend te maak, met die gedagte van heerlikheid. Die voorstelling van Gen. 5:3 wyk nie hiervan af nie; Set is die voortsetter van die geslag van Adam en is as sodanig die vooltsetter van die heerlikheid wat God aan Adam, as sy beeld, verleen het. Ook in Gen. 9: 1-7, die inleiding tot die Godsverbond met Noag, word die feit dat die mens die beeld van God is, weer verbind met die heerlikheid, die heerskappy van die mens. 'n Mens mag 'n medemens nie doodslaan nie omdat die doodslag van 'n medemens inbreuk is op die heerlikheid van God, in so verre die mens die beeld is van God.

18) vgl. G. KIтTEL, Theologische Wörterbuch zum Neuen Testament, Stuttgart 1935. Zweiter Band, S. 386. 30ff.

14) Rep. VI. 509.

15) vgl. Theol. Wörterb. z. N.T. Zweiter Bank, S. 387.

10) beçalménoe is beste te vertaal met: „as ons beeld"; hierna word dit nader bespreek. 
Sonder uitsondering vertaal die Septuagint in hierdie gevalle die hebreeuse woord, çèlem, met eikōn. Maar behalwe die kanonieke, bevat die Septuagint ook apokriefe literatuur waarin die sienswyse wat hierbo uiteengesit is, versterking vind. Sir. 17:2 en 3 verbind ook die heerskappy, die gesag van die mens met die feit dat hy geskape is om te wees beeld van God (kat' eikona autou). Om nog 'n ander voorbeeld te noem: Met die opkoms van die joodse wysheids-literatuur, het dit gebruik geword om die wysheid as ' $t$ ware te verpersoonlik en dit dan op te vat as die beeld van God; in dié sin spreek die apokriefe boek, Die Wysheid van Salomo 7:25 van die Wysheid as die manifestasie van die mag van God en die onvermengde uitvloeisel van die heerlikheid van die Almagtige. Die onmiddellike belang van die sinsnede is dat ook hier die reeds genoemde band gelê word tussen die beeld van God en die heerlikheid van God. Met 'n taamlike mate van sekerheid kan dus gekonstateer word dat in die Ou Testament en in die Septuagint, net soos in die griekse hellenistiese voorstellinge, aan die begrip van die beeld van God steeds verbind is dié van die heerlikheid van God.

Om hierdie verband ook in die Nuwe Testament aan te toon, kan ons weer aansluiting soek by Sap. Sal. 7:25. Die Nuwe Testament betrek naamlik die voorstelling van die Jodedom oor die gehypostaseerde Wysheid steeds op Christus. So is sommige eksegete van oordeel dat Hebr. 1: 3 'n direkte ontlening aan Sap. 7:25 is; maar dan word natuurlik nie die Wysheid nie maar Christus verheerlik: $\mathrm{Hy}$ is die afspieäling (apaugasma) van die heerlikheid van God en die stempel (charaktēr) van die wese van God. ${ }^{17}$ ) Vernaamste betekenis van hierdie passage vir ons ondersoek is dat hiermee ook in die Nuwe Testament die verband gelê word tussen die beeld van God en die heerlikheid van God; ons dien ook daarop te let dat die verhouding van die beeld tot dit waarvan dit die beeld is, hier as onbemiddeld voorgestel word. Van gelyke waarde is die feit dat Jak. 3:9 die belastering van 'n mens verbied om dat hy die beeld van God is; hiermee wotd geïmpliseer dat belastering van 'n mens gelykstaan aan die skending van Gods majesteit, sy heerlikheid. Terwyl Jakobus hierdie opvatting dank aan die Genesis-voorstelling van die mens as die beeld van $\left(\mathrm{God}^{18}\right)$ is die verband tussen beeld en heerlikheid van God ook hier duidelik. Ook Paulus maak gebruik van die Genesisvoorstelling wanneer hy in I Kor. 11: 7 die man die beeld en heerlikheid van God noem. ${ }^{19}$ ) In hierdie uitspraak is die verband tussen die beeld en die heerlikheid van God opsigtelik.

'n Verdere eis is dat ons ons ook rekenskap sal gee van die betrekking tussen God en sy beeld. Tot hiertoe het ons eenvoudig geponeer dat die

17) vgl. J. Moffat, Epistle to the Hebreus (I.C.C.), Edinburgh, 1924, p. 6.

18) vgl, veral Gen. 9:6.

19) vgl. veral Gen. $1: 26$ en 27 . 
mens die beeld van God is volgens die anthropologie van die Ou Testament en deels volgens dié van die Nuwe Testament. Die stelling sou ook geen beswaar opgelewer het nie as die Dogmatiek dit maar nie van oudsher ook anders geïnterpreteer het nie en die beçèlem van Gen. 1:26 vertaal het met: „na ons beeld". Dit het gelei tot die gevolgtrekking dat die beeld van God 'n middelwese is tussen God en die mens. Die mens sou dan as beelddraer van God in werklikheid die beeld wees van die beeld van God. Die voorstelling het eintlik al by Mrlanchton voorgekom waar hy poneer, nec tamen mihi displicet dici, totum Adam creatum esse ad archetypum Filium Dei, qui est substantialis imago aeterni Patris. . .20) Andersyds het hierdie opvatting die veel omstrede probleem opgewerp: waarin bestaan die beeld van God in die mens?

Die hele misverstand het, skyn dit my, sy oorsprong in die Septuagint se woordelikse vertaling van die samestelling, beçalmēnu in Gen. 1:26 met kat' eikona. Nou kan die hebreeuse preposisie be in bepaalde gevalle wel die betekenis van die griekse kata (,volgens") hê. Die oorwegende betekenis van be in die Genesis-passages is egter volgens die contextus weer te gee met, ,as". Gen. 1:26 is dan beter te vertaal met: „Laat ons mense mak as ons beeld". Dat die Septuagint die sinsnede vertaal het op 'n wyse wat dit vatbaar maak vir tweeërlei opvatting, is te wyte enersyds aan die strewe van die vertalers in die grieks om die hebreeuse teks woordeliks te volg; andersyds het kat' eikona al heeltemal 'n preposisionele betekenis aangeneem, gelykstaande aan kata alleen. Bewys vir die laaste stelling lewer Sir. 17:3 wat handel oor die skepping van die mens en waar kath' heauton en kat' eikona autou as sinonieme uitdrukkinge gebesig word. Ons tref dit ook an in die taal van Paulus; Kol. 3:10 spreek van die nuwe mens vernuwe tot kennis kat' eikona tou ktisantos. In Ef. 4:24 bedoel hy presies dieselfde as hy spreek van die nuwe mens ton kata Theon ktisthenta. Kat' eikona en kata word duidelik sinoniem gebruik. Bygevolg is dit ook heeltemal verstaanbaar waarom Paulus in I Kor. 11: 7 kan sê, ,'n man is die beeld en heerlikheid van God". Die nutestamentiese voorstelling van die mens as geskep kat' eikona tou Theou, veronderstel 'n onmiddellike verband tussen God en die mens. Die mens is die beeld van God. So kan Paulus ook in die Areopagusrede die woorde van die heidense digter Aratus herhaal sonder om sy eie opvatting te verloën: "Want ons is ook sy (God se) geslag." ${ }^{21}$ ) Hierbo het ons die geleentheid gehad om die onbemiddelde betrekking tussen die beeld en dit waarvan dit die beeld is, in die griekse literatuur aan te toon; 'n dergelike noue betrekking tussen God en sy beeld, spreek ook uit die Nuwe Testament.

Om met hierdie twee formele bepalinge te volstaan, naanlik dat die beeld van God ook deur die Nuwe Testament opgevat word eerstens in

20) Aangehaal deur P. J. Muller, Handboek der Dogmatick. Groningen, 1895, bls. 97 .

21) Aratus, Phaenomena 5. Sien Hnd. 17:28 en 29. 
verbinding met die begrip van heerlikheid en tweedens as sonder bemiddeling, kan ons nou ons aandag gee aan die vraag: Wie is volgens die Nuwe Testament die beeld van God? In direkte voortsetting van die opvatting van die Ou Testament, leer Hnd. 17:28, 29; 1 Kor. 11: 7 en Jak 3: 9 dat die mens die beeld van God is. Ons moet hierdie voortsetting van die outestamentiese opvatting egter besien as 'n formele, want die Nuwe Testament kom met 'n belangrike verdieping van die opvatting na vore wanneer dit in die allereerste plek Christus die beeld en die heerlikheid van God noem. In Il Kor. 4:4 spreek Paulus van, „.. . die verligting van die Evangelie van Christus, $(\mathrm{Hy})$ wat die beeld van God is”. In Kol. 1: 15 heet Hy, , die Beeld van die onsienlike God”; $\mathrm{Hy}$ is die eersgeborene van die hele skepping; alle dinge is deur Hom in die hemel en op die aarde. Van onmiddellike betekenis vir ons ondersoek is die feit dat ook met die beeld-wees van Christus verbind is die gedagte van majesteit, heerskappy en heerlikheid, ${ }^{22}$ ) sy heerlikheid strek egter oor die grense van die aardse tot die hemelse dinge (Fil. 2: 10, 11; I Kor. 15: 28a; vgl. Mt. 11:27, 28:18; II Kor. 8:9; vgl. Joh. 17:5). Uit die bogenoemde twee tekste leer ons reeds die onbemiddelde betrekking tussen God en sy beeld, Christus, ken; dit word verder bevestig deur die uitspraak van Fil. 2: 6, „Hy wat in die gestalte van God was, het dit geen roof geag om aan God gelyk te wees nie". Vgl. ook Joh. 14: 9b en 12: 45.

Ons het daarop gewys dat die basiese voorstelling van die mens as beeld van God in die Nuwe Testament, teruggaan op die outestamentiese; ook die voorstelling van Christus as beeld van God is uit die bron afkomstig. As Paulus in sy noem van die mens as die beeld van God (I Kor. 11:7) teruggegryp het op Gen. 1:26, dan doen hy dieselfde as hy in I Kor. 15: 45 van Christus spreek as die tweede Adam; en dat hy dit in verband wil bring met die voorstelling van die beeld van God, blyk in die besonder uit I Kor. 15:47-49. Schlatter noem Paulus se verbinding van Christus met die voorstelling van die beeld van God selfs die sentrum van die pauliniese teologie ${ }^{23}$ ) Ons moet dus volstaan met die feit dat die Nuwe Testament én die mens én Christus die beeld en die heerlikheid van God noem. En tog maak die Nuwe Testament 'n geweldige onderskeid tussen die mens as beeld van God en Christus as beeld en heerlikheid van God. Anders sou die stelling van Paulus dat dié wat Christus aangeneem het, verander word na die beeld en heerlikheid van Christus, sonder sin wees (vgl. I Kor. 15:49; II Kor. 3: 18; Kol. 3: 8-12; Ef. 4: 17-24 en Rom 8: 29). Die ou- en nutestamentiese

21) A. Schlıttrer, Paulus der Bote Jesu. Stuttgart, 1934, S. 527: „.. . worin de Herrlichkeit des Christus bestehe. Er hat sie deshalb, weil er das Bild Gottes ist. Seine Herrlichkeit ist somit als sein Besitz und Kennzeichen gedacht."

23) A. Schlatter, a.a.O. S. 528: „Indem Paulus den Christus im Anschluss an Genes. 1, 26 das Bild Gottes nennt, spricht er den zentralsten Satz seiner Theologie aus. 
voorstelling van die mens as beeld van God en die nutestamentiese voorstelling van Christus as beeld van God, is dus só verskillend van mekaar, dat alleen ' $n$ radikale verandering van sy bestaande toestand die mens in ooreenstemming kan bring met Christus, die beeld van God. Wat hierdie bestaande toestand van die mens is, leer Paulus o.a. in Rom. 3:23: "Want alger het gesondig en skiet te kort in die heerlikheid van God"; 'n grafiese tekening van die bestaande toestand, deur Paulus by voorkeur genoem "die oue mens", volg in Ef. 4:17-19. Dit bestaan in 'n ,gemoeds-verdwasing", ,verstands-verduisterdheid", en ,vervreemding van die lewe met God"; dit uit hom in ongebondenheid, hebsug en onreinheid. Daarteenoor staan die "nuwe mens" wat volgens Kol. 3: 10 vernuwe is tot kennis na die beeld van sy Skepper. Kol. 3: 12 noem die só vernude mens 'n uitverkorene van God. Op ondubbelsinnige wyse maak Paulus dit tot eis dat die beeld van God in die mens herstel moet word; en met die herstel van die mens se beeld-wees is ten nouste verbonde die feit dat Christus beeld is van God. Die hernude mens, die uitverkorene, is deur God van tevore verordineer om te wees gelykvormig aan die beeld van sy Seun (Rom 8:29); al onderskeid tussen die gelowige as beeld van God en Christus as beeld van God is dan dat Christus die eersgeborene is onder vele broeders. Krag van die uitdrukking is dit, dat die Christen deur Christus weer beeld word in die sin wat Gen. 1:26 dit bedoel het. ${ }^{24}$ )

Die spreek van Christus, Seun van God en beeld van God, en van die gelowige Christen as gelykvormig aan sy beeld en as broers van Christus, rig die aandag onwillekeurig daarop om aan die nutestamentiese voorstelling van die beeld van God te verbind die Godseunskap. Trouens reeds Lukas, wanneer hy Adam, wat die beeld van God is, seun van God noem (3: 38), bevestig ons opvatting dat daar 'n verband lê tussen die begrippe „beeld van God" en ,,kind van God". Wanneer hy verder ook Jesus, wat beeld van God is, voorstel as Seun van God en as direkte afstammeling van Adam, die seun van God (3:23), vertoon hy 'n treffende ooreenkoms met die leer van Paulus in I Kor. 15: 45. Rom. 8: 21, in aansluiting by die verse wat handel oor die gelowiges as gelykvormig aan die beeld van Christus, spreek van die „vryheid van die heerlikheid van die kinders van God" as einddoel van die verlange van die hele skepping. Almal wat deur die Gees van God gelei word, hulle is kinders van God (vgl. Rom 8: 14, 15). En die aanname tot kinders van God maak die gelowige in die volle sin van die woord broers van Christus, sy medeerfgename en deelhebbers in sy heerlikheid (vgl. Rom 8:17 en Hebr. 2:10-11). Die eindbestemming van die skepping is die openbaarmaking van die kinders van God; Paulus (Rom 8:23) en Johannes (I Joh. 3:2) stel die volle verwerkliking van die Godkindskap van die gelowige as 'n eschatologiese gebeurtenis voor. Dit is 'n grootheid waarop gehoop word maar in die sekerheid van die vervulling van die hoop, handel die

${ }^{24}$ ) vgl. G. KITTEL, Theol. Wörterb. z.N.T. S. 395.5 - 15. 
gelowige reeds hier as kind van God (Rom 8: 25-30 en I Joh. 3: 3vv.; vgl. ook Ef. 5: 1). Netso spreek I Petrus 1: 14vv, ook van die gelowiges as kinders van God wat onder die verpligting staan om hul lewenswandel dienooreenkomstig in te rig.

Dis in hierdie sin dat ook die woorde van Jesus verstaan moet word: "Wees julle dan volmaak soos iulle Vader in die hemele volmaak is" (Mt. 5: 48; vgl. I Petr. 1: 15v.). Onwillekeurig let mens hier op die verband tussen die ou- en nutestamentiese voorstelling; Lev. 11:44, 19: $2 \mathrm{vv} ., 20: 7 \mathrm{vv}$. is ongetwyfeld die substratum waarop die genoemde nutestamentiese uitsprake rus. In die nutestamentiese voorstelling tref mens egter ' $n$ vetdieping van die begrip aan wat in die Ou Testament in só 'n mate nog nie voorkom nie.

Saamgevat, kom ons tot hierdie slotsom: Die Nuwe Testament leer dat om beeld van God te wees dieselfde is as om kind van God te wees; en uitsprake soos dié van Rom. 8: 29 en II Kor. 3: 18 leer ons dat die parallel eers voltooi is wanneer ons sê dat die herstel van die beeld van God in die mens, dieselfde is as die herstel van die gemeenskap met Christus. ${ }^{25}$ )

Beeld van God, Christusgemeenskap en Godkindskap is vir die opvatting van die Nuwe Testament dieselfde. Dit word soveel duideliker wanneer ons vra na die tyd van die wederherstelling van die beeld van God in die mens. Uit I Kor. 15: 49 en II Kor. 3: 18 leer ons dat dit 'n eschatologiese gebeure sal wees. Die beeld van God is vir die gelowige dus toekoms-besit. Maar Kol. 3: 10, Rom 8: 29 en Ef. 4: 23, 24 maak dit tot 'n gebeurtenis in die teenswoordige, nog tydens die aardse lewe van die gelowige. Die gelyktydigheid van hede en van toekoms ten opsigte van die beeld van God in die mens strek hom ook uit tot die Godkindskap van die mens. So spreek Paulus dan van die Godkindskap as teenwoordige besit (Rom. 8: 14; vgl. Mt. 5: 48 en I Petr. 1:14) en dan weer as eschatologiese besit (Rom. 8: 23; vgl. I Joh. $3: 2 b, 3$ ). Op dieselfde wyse is die gemeenskap met Christus tegelyk teenwoordig en hiernamaals. As teenwoordig word dit voorgestel deur Ef. 2: 4-7, Gal. 2: 20, Kol. 2: 6, 10, 12, 13; I Thess. 5: 10; Hebr. 3: 14; vgl. Joh. 17: 22. As toekomstig word dit geleer deur Kol. 3: 4; Tit. 2: 13; Hebr. 6: 18-2Ca. Van die gelowige mens as beeld van God en as kind van God en as lewend in en deur die gemeenskap met Christus, kan gelykelik gesê word: "das aber bedeutet dass sie ietzt schon ist und dass sie dennoch erst sein wird, dass sie gleichzeitig Haben und Nochnichthaben, dass ihre Eschatologie gegenwartskräftig und dass ihre Gegenwart eschatologisch verankert ist." 26 )

A. S. GEYSER

25) vgl. H. Wheeler Robinson, The Christian Doctrine of Man. Edinburgh, 1911. p. 140 sq.

26) G. KITTEL, a.a.O., S. 396. 